\title{
Komunikasi Agama di Dunia Virtual: Kajian terhadap Fanpage Santrionline
}

\author{
Anis Setiyawati, ${ }^{1}$ Akhriyadi Sofian, ${ }^{2 *}$ Mochamad Parmudi ${ }^{3}$ \\ 1,2,3Universitas Islam Negeri Walisongo Semarang - Indonesia
}

\begin{abstract}
Facebook is one of the social media (socmed) platform that's famous to people globally. Facebook has a fanpage that can accommodate limitless friendship. Millenials of santri are also fanpage users. Fanpage Santrionline is a media used to communicate amongst santri Nusantara. This article based on qualitative research with a descriptive analysis approach. Its research method was virtual ethnography and cyber media analysis. This analysis method consists of four levels: first, media space level, that used by santri to communicate, learn Islam, and do business. Second, the media archive level is an alternative narration to communicate the peaceful message. Third, media object level, media to interactive communication amongst the communities. Fourth, experiential stories, and experience to learn Islam amongst the followers of Fanpage Santrionline.

Facebook merupakan sebuah media sosial (medsos) yang banyak digunakan masyarakat. Facebok menyediakan fanpage atau laman yang dapat menampung pertemanan tak berbatas. Generasi milenial dari kalangan santri termasuk aktor pengguna fanpage. Fanpage Santrionline merupakan media santri Nusantara. Artikel ini berdasar pada riset kualitatif dengan pendekatan deskriptif analisis. Sedang metodenya ialah etnografi virtual dan metode analisis media siber. Metode analisis ini terdiri dari empat level yaitu: pertama, level ruang media (media space) sebagai media komunikasi santri, belajar agama, dan berbisnis. Kedua, level dokumen media (media archieve) sebagai narasi anternatif untuk menyampaikan pesan perdamaian. Level ketiga adalah objek media (media object) sebagai media komunikasi interaktif dengan anggota komunitas. Keempat adalah level pengalaman (experiential stories) yang memberikan pengalaman belajar agama diantara pengikut Fanpage Santrionline.
\end{abstract}

Keywords: Fanpage Santrionline; religious communication; virtual space

*Korespondensi Penulis: Akhriyadi Sofian (akhriyadi.sofian@walisongo.ac.id). Universitas Islam Negeri Walisongo, Jl. Prof. Dr. HAMKA, Km. 2, Ngaliyan Semarang, Indonesia 50185. 


\section{Pendahuluan}

Komunikasi di dunia virtual merupakan suatu isu yang menarik untuk dibahas. Hal ini disebabkan masyarakat beraktivitas di dunia virtual, di antaranya melakukan komunikasi bisnis, komunikasi keagamaan, dan komunikasi lainnya. Manusia menggunakan media sosial seperti Facebook, Instagram, Twitter, WhatsApp, dan sebagainya untuk melakukan komunikasi. Perkembangan teknologi seperti internet dapat memengaruhi kehidupan sosial agama masyarakat. Menurut Jon W. Anderson (2003:45) internet merupakan salah satu new media yang menjadi ukuran publik berdasarkan penggunaan yang dapat membuka interpretasi baru dan memfasilitasi khalayak untuk mengetahui dan menafsirkan ulang Islam dari berbagai sudut dan ekspresi agar orang Islam sendiri dan khalayak umum untuk datang dan mengkajinya. Menurut Hojsgaard dan Warburg (2005:61) dari penggunaan internet dalam ranah keagamaan istilah cyber religion semakin dikenal. Salah satunya adalah aktivitas keagamaan masyarakat kontemporer dengan memvirtualisasi interaksi agama dan budaya secara intensif dan interaktif dengan menggunakan pendekatan ilmiah, seni, dan agama dalam kehidupan (Ayun et al. 2014:137).

Komunikasi Islam merupakan sebuah proses penyampaian infomasi atau pesan dari seorang communicator (pihak pemberi informasi) kepada communicant (pihak penerima informasi) untuk menjalin hubungan agar menghadirkan sebuah kedamaian, keramahan, dan keselamatan. Komunikasi Islam merupakan komunikasi yang memiliki manfaat dunia dan akhirat. Kajian komunikasi Islam meliputi komunikasi manusia dengan Tuhan, komunikasi manusia dengan dirinya, dan komunikasi antar manusia (Hefni 2015:14).

Banyak masyarakat yang tergesa-gesa menyebar informasi ketika mereka dalam posisi senang me-reply dan me-share pesan yang diterima tanpa mempertimbangkan kebenaran dan manfaat bagi dirinya dan masyarakat. Penyebaran informasi tersebut dapat memicu sebuah kesalahpahaman antar individu di dunia virtual, bahkan dapat berujung perpecahan di dunia nyata. Perilaku keagamaan secara kontekstual di dunia virtual bersumber dari sosial media. Sosial media sering dianggap agama. Menurut Nuruddin (2018:xi), jika ajaran agama itu sumber kebenaran dalam perilaku, maka ketika seseorang mempercayai begitu saja informasi dari media sosial, maka ia telah menjadikannya sebagai agama. Media sosial juga sebagai penuntun kegiatan sehari-hari. Jika seseorang tanpa sikap kritis, mengecek kebenaran informasi di media sosial, maka nyata ia telah menganggap media sosial sebagai agama. Pernyataan tersebut bertujuan untuk mengembalikan ajaran murni dan suci keagamaan (Nuruddin 2018:x-xi).

Beberapa penelitian terdahulu terkait dengan kajian ini diantaranya ialah karya Ulya (2018) mengenai problem dan solusi religiusitas di tengah lingkaran hoax era post-truth menyatakan bahwa internet memengaruhi religiusitas publik. Media sosial misalnya dapat mempengaruhi cara seseorang untuk menjadi lebih religius. Religiusitas atau keberagamaan ini diartikan sebagai sebuah pengalaman keagamaan. Para pengguna cyber cenderung lebih suka belajar ilmu agama di media sosial dari orang yang dianggap menarik. 
Mereka belajar ilmu agama di situs-situs keagamaan karena lebih praktis. Pengguna media sosial cenderung menyebar berita di media sosial tanpa melihat bagaimana kebenaran dan manfaat bagi dirinya karena didukung oleh sifat media sosial yang bebas untuk mengekspresikan diri sebagai produsen maupun konsumen teks. Oleh sebab itu pengalaman keagamaan penting untuk membuat para pengguna cybercpace bijak dalam bermedia sosial (Ulya 2018:293).

Para pengguna cyberspace merupakan aktivis yang menciptakan sebuah makna dan subjektivitas berdasarkan perspektif budaya mereka masing-masing. Sebuah komunitas terdiri dari setiap individu memiliki budaya yang berbeda, namun komunitas di ranah virtual dapat membentuk satu budaya yang spesifik dengan melakukan aktivitas virtual yang sama. Hasil studi dari Norris (2002) yang dikutip oleh Ridho (2017:3) menyebut bahwa internet dapat menjadi sarana untuk membangun komunitas virtual, selain itu internet dapat meningkatkan kapital sosial dengan adanya saling tukar informasi antar penggunanya.

Penelitian Franzia, Piliang, dan Saidi (2016) mengenai visualisasi identitas Islam dalam komunitas virtual Palanta Urang Awak Minangkabau menyatakan bahwa komunitas virtual Palanta Urang Awak Minangkabau menggunakan Facebook sebagai tempat berkumpul dan bercakap di dunia maya untuk memupuk persaudaraan masyarakat Minangkabau dengan menggunakan Adat Basandi Syarak, Syarak Basyandi Kitabullah atau adat yang berlandaskan agama Islam dan al-Qur'an yang dideklarasikan sebagai identitas Islam masyarakat Minangkabau dimanapun berada di dunia virtual. Prinsip persaudaraan pada empat pilar yaitu ta'āruf (saling mengenal), tafāhum (saling memahami), ta'āwun (saling menolong), dan tarāḥum (saling menyayangi). Komunitas ini sebagai komunitas terbuka yang disatukan dalam jejaring Facebook sebagai tempat untuk memperbincangkan segala topik seperti persoalan dapur, adat, politik dan berita aktual (Franzia et al. 2016:168).

Adapun Fanpage Santrionline merupakan bentuk produktivitas santri di dunia virtual sebagai media komunikasi Islam untuk memproduksi konten dengan mengoptimalkan berbagai sumber ilmu termasuk kyai, ulama, kitab, buku, hasil pertemuan, tautan yang sejalan dengan ideologi yang dikembangkan. Konten dalam Fanpage Santrionline tidak pernah asal-asalan, selalu mengacu pada sumber Islam yang otoritatif dan selaras dengan ideologi Santrionline. Komunikasi Islam dalam ruang Fanpage Santrionline merupakan komunikasi yang terjadi antara communicator (pemberi informasi) dengan communicant (penerima Informasi) dan antar communicant yang dibingkai dalam tradisi beragama NU (Nahdhatul 'Ulama), santri, dan Indonesia di ranah virtual. Artikel ini hendak melihat bagaimana kebiasaan para komunitas Fanpage Santrionline yang bermuara pada strategi komunikasi Islam yang dibentuk oleh para produsen teks dalam Fanpage Santrionline. Informasi salah (hoax) yang sarat dengan nuansa SARA dan konflik serta bid'ah dalam agama Islam diluruskan dengan komunikasi yang Islami dengan tetap mengacu pada sumber informasi yang otoritatif. 
Artikel ini bersumber pada riset kualitatif dengan menggunakan pendekatan deskriptif analisis. Sedang metode yang dipakai adalah metode etnografi virtual. Metode etnografi virtual merupakan metode penelitian kualitatif dalam dunia virtual. Selama penelitian penulis bertindak sebagai pengamat dan juga terlibat dalam Fanpage Santrionline. Peneliti mengamati, dan memberi tanggapan berupa like dan komentar di Fanpage Santrionline sebagai partisipan untuk saling berinteraksi. Tahap selanjutnya adalah melakukan koleksi dan analisis data kemudian melakukan interpretasi data sesuai fakta yang diperoleh di lapangan. Jorgen Skageby menjelaskan bahwa etnografi virtual atau online ethnographical merupakan metode yang dilakukan secara kualitatif untuk memahami apa yang terjadi pada komunitas virtual. Teknik pengumpulan data secara observasi dan wawancara secara online untuk memaparkan komunikasi yang dilakukan oleh komunitas masyarakat cyber di dunia virtual (Nasrullah 2017:9).

Komunikasi dalam dunia virtual merupakan komunikasi yang tidak lepas dari simbol dari sebuah bahasa teks. Bahasa teks meliputi tulisan, gambar, suara, dan video. Setiap isyarat yang dimaknai sesuai kesepakatan bersama memiliki pengaruh dan arti penting bagi setiap individu. Teori interaksi simbolik menurut George Herbert Mead memiliki tiga unsur dasar pertama, mind (pikiran) yaitu kemampuan untuk memaknai simbol yang digunakan untuk berinteraksi. Kedua, self (diri pribadi) yaitu setiap individu memiliki kesempatan untuk mengembangkan diri sendiri melalui interaksi. Ketiga, society (masyarakat) merupakan penciptaan suatu hubungan sosial. Ketiga unsur dasar pemikiran
Mead tersebut dapat menjadi sebuah landasan untuk melihat bagaimana cybercommunity saling berkomunikasi (Morissan 2017:128-32).

Teori interaksi simbolik ini merupakan teori yang relevan karena dapat menganalisis bagaimana communicator dan communicant sebagai cybercommunity memaknai simbol dalam tulisan, gambar, video, dan suara yang terdapat dalam Fanpage Santrionline. Pemaknaan simbol tersebut bermaksud untuk mempresentasikan apa makna yang dimaksud communicator untuk berkomunikasi dengan communicant dan sebaliknya dan juga antar cybercommunity sebagai pengunjung Fanpage Santrionline. Masyarakat cyber menggunakan simbol-simbol untuk menyampaikan pesan untuk berkomunikasi dengan sesama.

\section{Internet dan Pemanfaatan Medsos di Indonesia}

Menurut Lim (2002:273) bahwa internet masuk di Indonesia pada awal krisis politik pada tahun 1990-an. Namun, pada awalnya internet hanya untuk sebagian masyarakat tertentu. Pada saat itu media informasi Indonesia berada di bawah kendali rezim Soeharto. Rezim Soeharto memanfaatkan media untuk menyebarkan propagandanya untuk meligitimasi dan menyebarkan identitas negara perkembangan progresif. Teknolgi komunikasi dan media khususnya satelit dan televisi sengaja digunakan untuk membangun identitas nasional di bawah negara, sehingga menghalangi masyarakat mengakses informasi selain apa yang disediakan oleh negara.

Berdasarkan hasil Studi Polling Indonesia yang bekerja sama dengan Asosiasi Penyelenggara Jasa 
Internet Indonesia (APJII) yang dilaporkan oleh Pratomo (2019) menyebutkan bahwa jumlah pengguna internet di Indonesia meningkat sebanyak 10,12\% pada tahun 2018. Sebanyak 171,17 juta pengguna atau sebesar $64,8 \%$ dari penduduk Indonesia telah menjadi pengguna internet dari total populasi sejumlah 264 juta jiwa penduduk Indonesia. Angka ini meningkat dari tahun 2017 ketika penetrasi internet di Indonesia pada angka $54,86 \%$ dari total populasi penduduk di Indonesia. Perkembangan internet di Indonesia dapat dilihat berdasarkan data dari APJII per tahunnya. Sejak tahun 1998, pengguna internet di Indonesia sejumlah 0,5 juta pengguna, hingga pada tahun 2018 mencapai 171,17 juta pengguna internet. Pertumbuhan internet dapat dilihat pada Diagram 1.

Peningkatan jumlah pengguna internet di Indonesia seiring dengan peningkatan setiap tahunnya tidak lepas dari campur tangan generasi muda. Pengguna internet di Indonesia paling banyak adalah anak usia 15 sampai 19 tahun dengan persentase mencapai $91 \%$. Jumlah tersebut menunjukkan bahwa penggunaan internet di Indonesia di dominasi oleh generasi muda, sehingga perlu adanya pengawasan dalam penggunaan. Berikut penetrasi penggguna internet Indonesia pada tahun 2018 berdasarkan umur: (lihat Diagram 2)

Jika dilihat dari pengguna internet adalah generasi muda terutama usia 15-19 tahun yang merupakan usia anak Sekolah Menengah Atas (SMA) yang mencapai 91\% dan usia 20-24 tahun yang merupakan usia kuliah sebanyak 88,5\% dan dihubungkan dengan alasan utama penggunaan internet adalah media sosial dan komunikasi melalui pesan, sedangkan aktivitas mencari data dan informasi mengenai sekolah dan kuliah hanya mencapai 9,6\% maka diperlukan langkah untuk meningkatkan konten yang positif di media sosial.

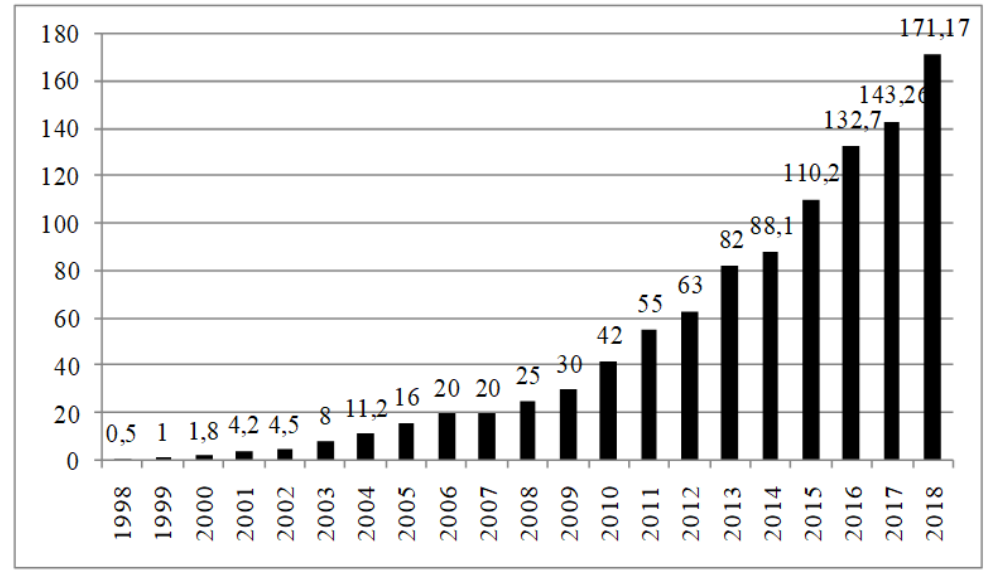

Diagram 1.

Pertumbuhan pengguna Internet Indonesia.

Sumber: Data olahan peneliti dari Asosiasi Penyelenggara Jasa Internet Indonesia (2018) 


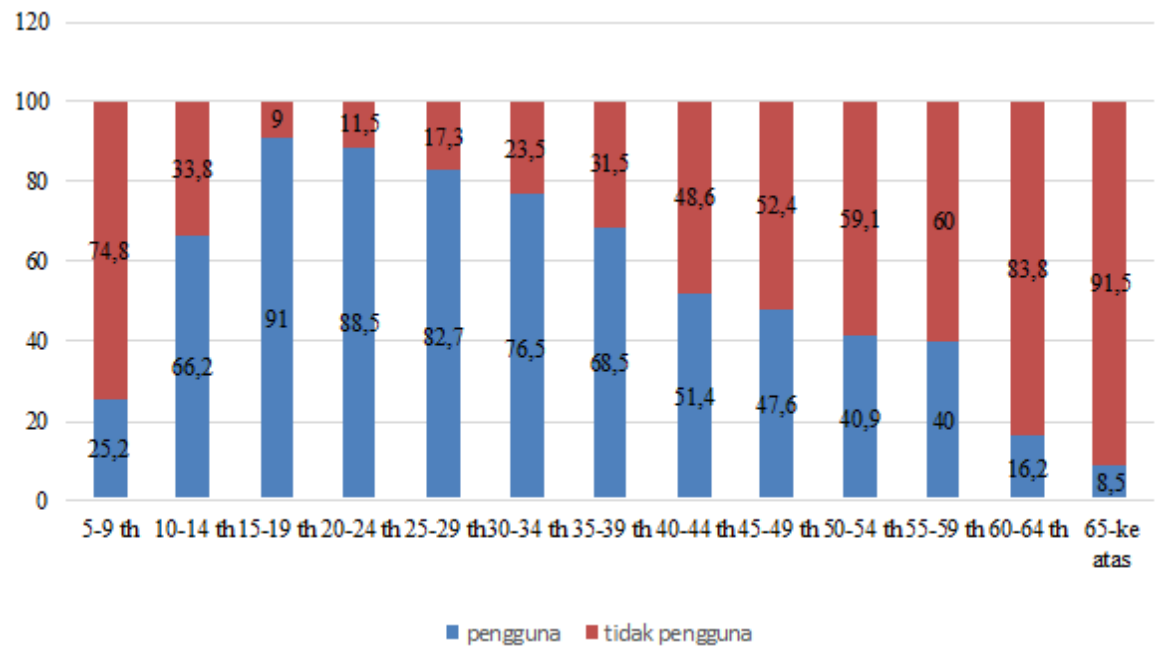

Diagram 2

Persentase pengguna internet Indonesia tahun 2018 berdasarkan umur.

Sumber: Data olahan peneliti dari survei Asosiasi Penyelenggara Jasa Internet Indonesia (2018)

Kita dapat memanfaatkan media sosial dengan bijak sebagai media komunikasi, pendidikan, bisnis, pengawasan, dan hiburan melihat tingginya akses internet terhadap media sosial. Media sosial adalah aplikasi teknologi informasi berbasis web 2.0 yang memiliki fasilitas untuk tergabung dengan pengguna lain untuk melakukan pertukaran konten atau user-generated content secara virtual atau online (Arifianto 2018:68).

Berdasarkan data dari We are Social and Hootsuite yang dikutip oleh Pertiwi (2019), jumlah pengguna media sosial di Indonesia pada tahun 2019 naik sebesar 20 juta dari jumlah pengguna media sosial tahun 2018 yang mencapai 130 juta, pada tahun 2019 pengguna media sosial di Indonesia mencapai 150 juta pengguna. Salah satu media sosial yang paling digandrungi di Indonesia adalah Facebook. Persentase penggunaan Facebook di Indonesia per bulan Januari 2019 mencapai 81\%. Facebook menjadi aplikasi media sosial yang unggul di Indonesia dibanding Instagram yang berada di bawah Facebook dengan persentase jumlah pengguna mencapai 80\%. Terdapat lima media sosial yang mencapai popularitas tertinggi yaitu Facebook, Instagram, Twitter, Snapchat, dan Linkedin. Di sisi lain, popularitas Facebook hanya dikalahkan oleh platform streaming YouTube yang mencapai $88 \%$ dan juga pesan instan WhatsApp dengan jumlah persentase mencapai 83\%.

Di tingkat dunia, Indonesia menempati urutan ketiga sebagai pengguna Facebook dengan jumlah 130 juta pengguna Facebook. Pengguna Facebook Indonesia terdiri dari 56\% pengguna laki-laki dan $44 \%$ pengguna perempuan. Sementara Instagram memiliki jumlah pengguna mencapai 62 juta pengguna aktif dengan persentase jumlah pengguna laki-laki 51\% dan pengguna perempuan mencapai $49 \%$. Adapun penggunaan Instagram di Indonesia mencapai 59 juta pengguna dan menempati urutan keempat 
di dunia. Selanjutnya pengguna Mikroblog Twitter di Indonesia memiliki jumlah pengguna mencapai 6,43 juta pengguna aktif bulanan dan menghantarkan Indonesia masuk di urutan kesepuluh di tingkat dunia. Pengguna Twitter lakilaki mencapai $65 \%$ sedangkan perempuan hanya 35\%. Adapun Linkedin di Indonesia memiliki 12 juta pengguna yang memiliki persentase pengguna perempuan mencapai $87 \%$ sehingga mengantarkan Indonesia menempati urutan kesepuluh sebagai negara pengguna Linkedin terbesar di dunia (Pertiwi 2019).

Aplikasi Facebook menyediakan ruang yang memudahkan khalayak untuk menulis dan berbagi tulisan dalam waktu yang cepat dan menjangkau masyarakat luas, tidak heran jika tingkat akses terhadap konten Facebook mencapai 50,7\%. Fanpage merupakan salah satu fasilitas yang ditawarkan oleh Facebook yang memiliki pengaruh besar terhadap massa karena jangkauan pertemanan yang tanpa batas dibanding dengan Facebook biasa. Disisi lain, berdasarkan data yang peneliti peroleh dari Randi Eka (2018) pada kenyataannya Facebook digunakan sebagai media penyebar informasi hoax yang mencapai $82,25 \%$ pada tahun 2018 yang dapat memperburuk komunikasi, oleh sebab itu diperlukan usaha yang keras agar generasi muda mencapai akselerasi penguasaan $e$-literacy yang tepat.

\section{Fanpage Santrionline}

Halaman Facebook atau biasa disebut Fanpage adalah sebuah ruang dalam Facebook yang berguna untuk membentuk komunitas yang ada di Facebook. Facebook memiliki berbagai jenis aplikasi termasuk pertemanan, grup, market place, halaman, video di watch, location, foto, cuaca, game, acara atau aktivitas, dan sebagainya. Fanpage tidak membatasi jumlah teman atau pengikut, tidak seperti Facebook yang hanya dapat mengonfimasi 5.000 pertemanan, sehingga ruang Fanpage lebih luas untuk berkomunikasi. Kita dapat menyesuaikan Fanpage dengan menerbitkan berita, menyelenggarakan acara, menambahkan aplikasi, dan sebagainya. Pengguna Facebook yang menyukai dan atau mengikuti Fanpage Santrionline secara otomatis akan menjadi pengikut sehingga dapat tergabung dalam komunitas.

Fanpage merupakan sebuah halaman Facebook yang menyediakan ruang untuk para fans sebuah akun atau penggemar berkumpul menjadi satu dalam komunitas. Fanpage menyediakan sebuah fitur layaknya Blog yang dapat digunakan sebagai ruang diskusi antar pengikut. Komunitas dapat menjadi produsen atau konsumen teks dalam Fanpage. Kelebihan penggunaan Fanpage adalah ruang pertemanan tanpa batas dan dilengkapi dengan fitur toko online dan iklan sehingga kita dapat mempromosikan konten dan bisnis yang kita jalankan.

Menurut Abdul Wahab yang dilansir dari YouTube/KompasTV, tujuan dari pembentukan Santrionline ini untuk media belajar santri, media untuk mengurangi penyebaran hoax agar tidak menimbulkan perpecahan, dan media untuk berbisnis. Konten yang diunggah berupa toleransi, nasionalisme, pendidikan, akhlak, bisnis, dan ibadah. Fanpage Santrionline menjadi wadah para santri untuk berkontribusi memberikan keberimbangan ilmu dan informasi tentang keIslaman di Indonesia berdasarkan visi Santrionline yaitu "Media santri Nusantara" dan sem- 
boyan " dari santri, oleh santri, untuk negeri" (Astaphala 2019; KompasTV 2017; Netmediatama 2018)

Fanpage Santrionline pada mulanya dibuat oleh akun Facebook bernama Kang Santri pada 8 Maret 2016. Nama akun dari Kang Santri menjadi Santrionline dirubah pada tanggal 18 Maret 2016. Meskipun Fanpage Santrionline tidak mengunggah konten setiap hari, namun setiap minggu tetap ada konten yang diunggah. Jeda pengunggahan konten biasanya 1-2 hari. Jumlah konten yang diunggah per hari rata-rata 1-2 konten dan maksimal sampai dengan 7 konten. Konten oleh Santrionline berisi promosi produk bisnis fashion muslim, tulisan beserta foto atau gambar, dan juga video. Konten tersebut terdapat dalam menu beranda, toko, postingan, ulasan, foto, video, tentang, komunitas, acara, dan grup di Fanpage Santrionline.

Pertama, adapun menu beranda merupakan halaman depan dari sebuah Facebook. Pada menu beranda terdapat kolom "tulis postingan" sehingga pengunjung dapat mengirim postingan di dinding atau wall Fanpage Santrionline. Beranda berisi semua menu yang berada dalam Fanpage Santrionline dan semua konten yang diunggah oleh Santrionline kecuali unggahan oleh komunitas. Kedua, menu toko merupakan ruang yang digunakan untuk berbisnis secara khusus. Menu toko berisi produk yang dijual oleh Santrionline dalam toko Distro Kang Santri, walaupun sebenarnya Distro Kang Santri telah memiliki Fanpage tersendiri. Kita dapat mencari produk yang dijual di toko dalam Fanpage Santrionline dengan menuliskan nama produk misalnya kaos pada kolom pencarian. Selanjut- nya kita dapat mengklik tombol berlangganan agar mendapat pemberitahuan mengenai produk unggulan Santrionline.

Ketiga, menu postingan menyediakan kolom untuk menulis konten. Pengunjung dapat menulis status dan mengunggah foto dan video di Fanpage dengan membuka menu postingan. Konten oleh admin dan juga pengunjung dapat dilihat di menu postingan, namun konten dari pengunjung hanya dapat dilihat ketika mengklik tombol "lihat postingan pengunjung" yang berada di samping tombol "bagikan foto" yang terdapat di bawah kolom untuk menulis status. Keempat, menu ulasan merupakan ruang yang digunakan untuk menilai dan merekomendasikan Fanpage Santrionline kepada pengguna Facebook lain. Pada menu ini kita dapat memberikan penilaian dengan tanda bintang. Parameter penilaian dengan cara menghitung jumlah bintang dari 1-5 bintang. Lima bintang berarti kita menilai bahwa Fanpage Santrionline sangat bagus dan direkomendasikan.

Kelima, menu foto dan video merupakan menu yang berisi foto dan video yang diunggah oleh admin Santrionline. Unggahan foto dan video merupakan sebuah menu yang dirangkum pada beranda dan juga menu postingan, namun pada menu foto adalah lebih khusus untuk menampilkan konten berupa foto atau gambar. Pada tanggal 28 Mei 2019, Fanpage Santrionline telah mengunggah foto sebanyak 4.648 foto, terdiri dari 2,4 ribu foto linimasi, 2,2 ribu unggahan seluler, 10 foto profil, 24 foto Instagram, dan 14 foto sampul. Video yang diunggah Santrionline berjumlah 576 video. Pada menu tentang, kita dapat melihat alamat kantor Santri- 
online, nomor telepon kantor, alamat E-mail, alamat Website, visi Fanpage, jenis halaman, dan juga Messenger. Fanpage Santrionline menyebutkan jenis Fanpage-nya sebagai media atau perusahaan berita.

Keenam, menu komunitas merupakan ruang yang digunakan oleh pengunjung Fanpage Santrionline untuk melakukan komunikasi dengan berdiskusi di kolom komentar, menyukai, dan membagikan konten dari pengunjung lain. Konten dari pengunjung yang diunggah di kolom "tulis postingan" pada menu postingan dan beranda ditampilkan secara khusus pada menu komunitas. Pengunjung dapat saling melihat konten, termasuk foto dari pengunjung yang menandai di alamat Santrionline dan melihat siapa saja yang telah bergabung dalam Fanpage Santrionline. Foto yang berada di alamat Santrionline berjumlah 30 foto. Kemudian di bawahnya berisi profil teman kita di Facebook yang menyukai Santrionline. Pada bulan Mei 2019 Fanpage Santrionline telah disukai sebanyak 280.683 pengguna Facebook dan diikuti oleh 293.167 pengguna Facebook. Terakhir bagian yang paling bawah berisi konten yang diunggah oleh anggota komunitas.

Ketujuh, menu acara menampilkan jadwal acara yang akan datang oleh admin. Menu acara berisi waktu, tempat, dan acara yang akan datang. Kedelapan, menu grup. Menu grup merupakan ruang yang berisi anggota komunitas Fanpage Santrionline. Grup ini bersifat publik sehingga setiap pengunjung dapat melihat dan bergabung dalam grup secara pribadi dan diundang oleh oleh anggota grup yang telah bergabung. Pada menu grup kita dapat melakukan komunikasi seperti dalam menu komunitas. Kita dapat mengirim postingan di grup ini. Anggota grup akan mendapat pemberitahuan jika terdapat aktivitas oleh salah satu anggota grup.

Aktualisasi berita menjadi faktor pendukung konsumsi publik yang tinggi. Namun, sifat media sosial yang menawarkan kecepatan digunakan oleh orang yang tidak memiliki kesadaran terhadap kebenaran dan kemanfaatan berita untuk menyebarluaskan kepada publik. Aktualisasi dan kecepatan media sosial memungkinkan penyebaran berita yang luas sehingga menyebabkan terjadinya interaksi timbal balik yang singkat. Berita bohong atau sesat informasi alias hoax merupakan suatu keniscayaan di ranah virtual, tidak terkecuali pada Fanpage Santrionline.

Salah satu isu agama yang diunggah admin adalah konten re-post dari K.H. Ma'ruf Khazin, seorang direktur Aswaja NU Jawa Timur mengenai klarifikasi meme yang membandingkan buku tuntunan sholat karya Drs. M. Rifa'i dengan buku tuntunan sholat karya Ustadz Yazid Jawas. Pada gambar meme tersebut menunjukkan jika buku karya Drs. Rifa'i disilang merah dan buku karangan Ustadz Yazid Jawas dicentang hijau. Meme tersebut memvisualisasikan bahwa buku karangan Drs. M. Rifa'i dianggap tidak dapat digunakan sebagai buku pedoman shalat (lihat gambar 1).

Pernyataan tidak layaknya penggunaan buku karya Drs. Rifa'i dibantah oleh K.H. Ma'ruf Khazin bahwa perbandingan tersebut tidaklah sebanding karena sebenarnya buku karangan Drs. Rifa'i merupakan rangkuman dari kitab Taqrib dalam madzab Syafi'iyah. Taqrib sendiri merupa- 


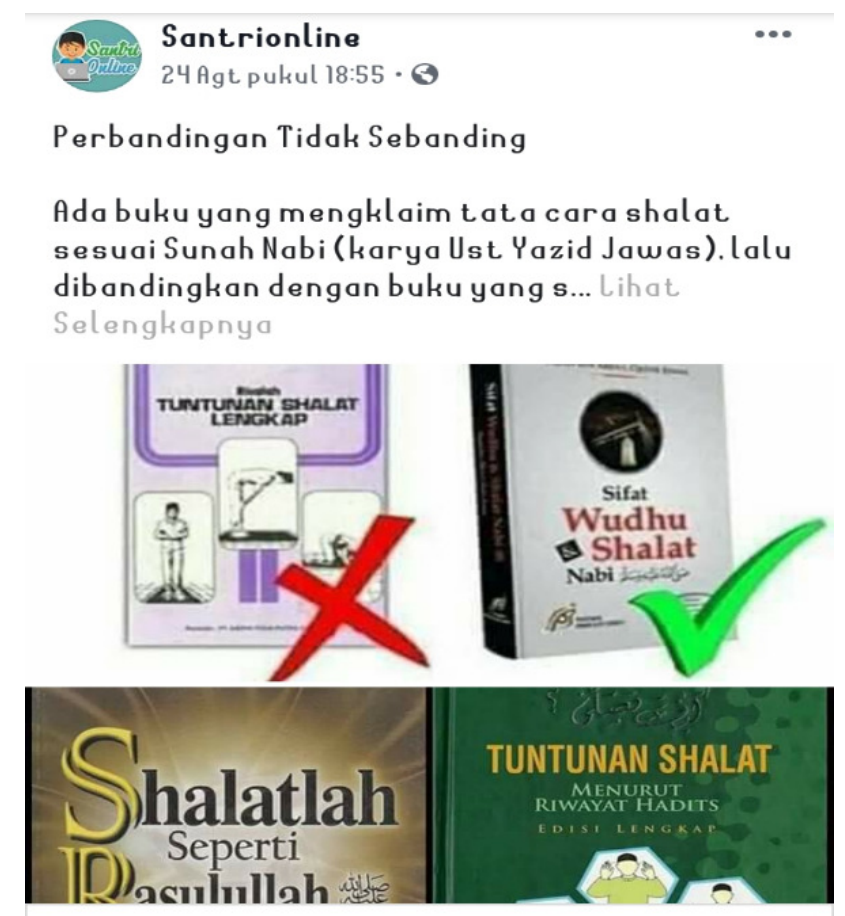

Gambar 1.

Postingan hoax. Sumber: Fanpage Santrionline

kan rangkuman dari kitab Majmu' atau Raudlah karya Imam Nawawi, sedangkan kitab karya Ustadz Yazid Jawas tidak bisa dibandingkan dengan Majmu'. Seharusnya kitab karya Ustadz Jawas dibandingkan dengan Taqrib agar memiliki perbandingan yang seimbang.

Berdasarkan konten tersebut dapat dilihat bahwa metode yang dilakukan admin adalah pengecekan berita dilakukan dengan membandingkan sumber rujukan yang satu dengan sumber rujukan lainnya. Fanpage Santrionline mengunggah ulang meme dan memberikan informasi klarifikasi mengenai kebenaran agar tidak menimbulkan kesalahpahaman masyarakat.
Jalan utama untuk mengantisipasi hoax terutama isu SARA adalah membangun kompetensi publik dalam menghadapi luapan informasi dengan literasi. Literasi media dan literasi agama penting dalam membangun komunikasi. Masyarakat harus dikenalkan literasi media yang berbasis karakter lokal melalui beberapa metode pada dasar-dasar kecukupan informasi, konsekuensi terhadap penyebaran informasi, kesadaran terhadap bentuk teknologi yang memengaruhi kehidupan, sampai dengan pengetahuan metodis untuk mengecek atau memverifikasi informasi yang dikonsumsi (Gumilar 2017:36). Literasi media berbasis karakter lokal dapat membantu masyarakat untuk memper- 
tahankan jati diri bangsa tanpa mengurangi wawasan internasionalnya.

Konten literasi pada Fanpage Santrionline terkait seputar budaya santri, karena Fanpage Santrionline dikelola oleh para santri. Konten di Fanpage Santrionline berisi pertama, konten dakwah yang memuat ajaran-ajaran Islam berupa aqidah, akhlak, dan syariat, serta muamalat. Konten ajaran agama Islam memvisualisasikan aktivitas keagamaan yang menjadi budaya masyarakat Nahdhatul Ulama (NU), yaitu budaya kumpul-kumpul di antaranya yasinan, tahlil, manaqib, istighasah dan sebagainya. Konten ajaran Islam berisi informasi keagamaan untuk melakukan ritual ibadah umat Islam. Konten dari sudut pandang kehidupan pesantren berupa nasihat kyai, kegiatan pesantren, dan cerita santri. Konten juga merupakan sesuatu yang sedang diviralkan. Literasi agama dilengkapi dengan pemasaran produk ala santri. Literasi agama dan wirausaha menjadi konten yang dikemas sesuai kebutuhan sasaran.

Konten literasi Santrionline berupa tulisan, gambar, dan video memvisualisasikan santri dan aktivitas kehidupan di lingkungan masyarakat. Konten literasi memvisualisasikan peran santri di masyarakat sebagai problem solver, uswatun hasanah atau tauladan yang baik, wirausahawan (entrepeneur), pemimpin (leader), dan motivator (Said dan Mutho 2017:231).

Di sisi lain, konten Santrionline juga bersumber dari komunitas yang membagikan konten di Fanpage Santrionline. Konten yang berasal dari beberapa anggota komunitas kurang mendapat perhatian dari komunitas Santrionline sendiri. Kita dapat melihat dari ruang virtual
Fanpage, konten yang berasal dari komunitas diatur (setting) tidak ditampilkan di beranda, sehingga tidak terbaca oleh komunitas. Ini dilakukan untuk mengantisipasi konten-konten yang tidak layak dikonsumsi anggota komunitas lainnya dan juga menyesuaikan dengan tujuan dari Fanpage Santrionline.

Tahap metodis literasi media untuk mengecek kebenaran informasi atau biasa disebut tabayyun yang dikonsumsi melalui Facebook, pengguna dapat menggunakan fitur report status dan kategorikan informasi hoax sebagai hatespeech (ujaran kebencian), harrasment (pelecehan), rude (kekasaran), and threatening (ancaman) atau aduan yang lainnya. Jika ada aduan dari netizen, maka biasanya Facebook akan menghapus status tersebut.

\section{Strategi Komunikasi Islam dalam Fanpage Santrionline}

Proses komunikasi pada hakikatnya merupakan proses penyampaian pikiran atau perasaan oleh seorang komunikator kepada komunikan. Onong Uchjana Effendy $(2008,2017)$ membagi proses komunikasi menjadi dua tahap yaitu secara primer dan secara sekunder. Proses komunikasi primer adalah penyampaian pikiran dan atau perasaan seseorang kepada orang lain dengan menggunakan simbol sebagai media. Simbol media primer dalam proses komunikasi adalah bahasa, isyarat, gambar, warna, dan lain sebagainya yang mampu menerjemahkan pikiran atau perasaan komunikator kepada komunikan.

Sedang proses komunikasi secara sekunder adalah penyampaian pesan oleh seseorang 
kepada orang lain dengan menggunakan alat atau sarana sebagai media kedua setelah memakai simbol pertama. Seorang komunikator menggunakan media kedua untuk melancarkan komunikasinya agar menjangkau komunitas yang jauh dan banyak. Proses komunikasi ini adalah komunikasi di dunia virtual (Effendy 2008:12, 2017).

Castells (2001) yang dikutip oleh Nasrullah (2017:12) menegaskan bahwa relasi yang terjadi di dunia virtual terjadi karena computer communicated social networks dan lebih bersifat individualisme (networked individualism). Setiap individu merupakan aktor penting dalam pembentukan komunitas virtual dan jaringan individu merupakan pola-pola sosialnya.

\section{Komunikasi Islam dalam Fanpage Santrionline}

Fanpage merupakan suatu tempat yang didalamnya memiliki ruang bagi para fans atau pengemar yang memiliki tujuan yang sama, hal tersebut sejalan dengan pernyataan Jones (1997) yang dikutip oleh Prasetya (2017:361) bahwa komunitas dapat dilihat dari dua sisi, yaitu komunitas yang berdasarkan kepentingan bersama (communities of interest) dan komunitas berdasarkan lingkungan yang sama (place based community). Selanjutnya, Nasrullah (2017:71) menegaskan bahwa komponen penting untuk melihat komunitas virtual pertama, komunitas virtual akan selalu ada dan bergantung pada kebutuhan setiap individu. Sebagian komunitas Santrionline tidak merupakan penggemar (fans) karena sebagian kecil dari keanggotaan komunitas tidak memihak kepada Santrionlione. Kedua, komunitas virtual tidak dibatasi oleh regulasi dan bahasa. Interaksi antar individu menggunakan bahasa teknologi yang global. Teks, tanda, dan pemaknaan berkembang di internet. Bentuk teks media siber adalah multimedia sehingga halaman di media siber memuat teks yang dikombinasikan dengan foto, video, musik, animasi, dan sebagainya yang melibatkan indera manusia. Teks yang digunakan dalam berkomunikasi di Fanpage Santrionline merupakan transformasi bahasa agama yang dipadukan dengan tanda dari aplikasi Facebook berupa like dan emoticon.

Konsep dasar sistem komunikasi Islam meliputi aspek kekerabatan yang dibentuk dari pola komunikasi dua arah atau hubungan timbal balik yang mengacu pada kepentingan umat, ajaran Islam, dan memperhatikan aspek psikologis, sosiologis, dan agama. Sistem komunikasi Islam pada hakikatnya merupakan pengorganisasian pesan dakwah yang bertujuan untuk memengaruhi perilaku manusia untuk berjalan beriringan dan saling mengerti antar sesama. Sistem komunikasi Islam meliputi: a) Sekumpulan unsur komunikasi yang terdiri dari komunikator, komunikan, pesan, dan media; b) Tujuan sistem komunikasi yaitu penyebarluasan informasi pada umat atau khalayak, membentuk citra positif, brand awareness, dan persuasi; c) Wujud atau hasil proses komunikasi dalam jangka waktu tertentu pada media massa; d) Pengelolaan bahan atau data dan energi berupa berita, artikel, straight atau depth news, tajuk rencana, fact finding, dan lain sebagainya (Rahmadi 1990 dalam Hasanah 2016:16).

Konten menjadi salah satu komponen penting dalam pengembangan strategi komunikasi. Isi 
konten dan kreativitas konten merupakan daya untuk meningkatkan "edgerank". Konten dalam Fanpage dapat memengaruhi tingkat perluasan jaringan komunikasi dilihat dari edgerank. Edgerank merupakan algoritma yang menentukan apakah postingan di halaman Facebook akan muncul paling atas, tergerus ke bawah, atau bahkan tidak muncul sama sekali. Edgerank dibuat oleh Facebook untuk menghapus updatean teman Facebook, halaman Facebook yang kita sukai, atau grup yang kita tergabung kita ikuti. Jadi kesimpulannya kita menghapus apa yang tidak penting atau tidak ingin kita tampilkan di news feed (beranda Facebook) kita.

Edgerank dipengaruhi oleh tiga komponen yaitu affinity, weight, dan time decay. Affinity adalah poin penilaian dari seberapa sering para penyuka halaman berinteraksi dengan halaman Facebook kita, memberikan like konten yang kita unggah, memberikan komentar positif atau negatif, dan membagikan konten di timeline Facebook mereka atau teman mereka. Weight adalah poin penilaian berdasarkan seberapa banyak pengikut Fanpage membagikan (share), menyukai (like), mengomentari (comment) pada satu post. Sedangkan time decay adalah selisih waktu seberapa lama sebuah postingan sudah Anda terbitkan. Semakin sering kita mengupdate konten di halaman Facebook maka semakin besar nilai edgerank Anda. Jadi singkatnya jika nilai edgeranknya semakin tinggi maka semakin besar kemungkinan untuk muncul di news feed pengikuthalaman.

Kreativitas konten dalam Fanpage Santrionline berbentuk gambar yang berisi tulisan dan video yang berisi gambar dan tulisan. Kreativitas konten bertujuan untuk membentuk kesadaran merk (brand awareness), sikap terhadap merk (brand attitude), dan media sumber (source media). Pada dunia pemasaran, brand awareness dan brand attitude penting untuk memengaruhi konsumen. Brand awareness merupakan kemampuan konsumen untuk mengingat merk, sehingga dapat dijadikan pertimbangan dalam berbagai alternatif dan pengambilan keputusan, sedangkan brand attitude merupakan pengalaman atau evaluasi terhadap merk (Timpal 2016:3).

Konten dalam Fanpage Santrionline merupakan narasi alternatif. Konten dikomunikasikan dengan sistem komunikasi Islam. Pola komunikasi yang terbentuk berdasarkan pada kepentingan umat, mengacu pada peraturan dasar agama Islam, sehingga pesan yang disampaikan membentuk prasangka positif dan meningkatkan brand awareness (daya ingat terhadap merk) Fanpage Santrionline. Pesan disusun dengan mempertimbangkan aspek psikologi, sosiologi, dan agama. Pola komunikasi segala arah diharapkan mendekatkan emosional khalayak dalam menjalankan komunikasi.

Strategi yang dapat digunakan melalui konten dari admin pengelola dalam menghadapi berita hoax yang mengatasnamakan agama melalui konten narasi tandingan yaitu narasi alternatif. Jenis narasi tandingan ada dua, yaitu kontranarasi dan narasi alternatif. Kontranarasi merupakan narasi yang bertujuan untuk menghadapi langsung orang yang menyiarkan berita dan melawan pikiran dan menentang kepercayaan otoritas penyebar hoax, sedangkan narasi alternatif merupakan narasi penguatan ide-ide positif yang bertujuan untuk menciptakan debat alternatif di masyarakat dan menawarkan 
pandangan yang berbeda dalam melihat masalah (Ali-Fauzi 2019:19-22).

Adapun strategi pengendalian pesan dalam Fanpage Santrionline ialah komunikator melakukan penarikan kesimpulan atau menyerahkan ke khalayak. Komunikator atau admin mengemukakan pendapat berdasarkan sumber yang jelas berupa qoul kyai atau ulama yang bersumber dari kitab, seminar atau pengajian, dan media sosial lainnya. Ketika konten diserahkan kepada khalayak untuk direpresentasikan, komunikator atau admin memberikan pendapatnya berdasarkan referensi, selanjutnya admin meminta pengunjung untuk merepresentasikan dengan referensi masing-masing.

Strategi komunikasi Santrionline untuk mencapai visi dan misinya menggunakan simbol dan persepsi. Simbol dan persepsi digunakan untuk mengenalkan media dan membentuk citra media. Fanpage Santrionline ingin membentuk citra sebagai media santri Nusantara. Santrionline ingin menjadi media untuk berkreasi santri Indonesia, media belajar, dan media komunikasi penangkal hoax di dunia virtual. Slogan dari santri, oleh santri, untuk negeri, dilihat dari peluang seorang santri berkreasi di dunia virtual yang menghasilkan karya yang bermanfaat untuk bangsa. Peluang demokrasi di media sosial menjadikan santri sebagai bagian dari negara untuk berperan dalam pembangunan agama (Astaphala 2019).

Citra merupakan gambaran tentang objek di pikiran khalayak atau konsumen (Kriyantono, 2006: 355; dalam Yoni, Pascarani, dan Joni 2017:12). Citra dibentuk melalui terpaan stimulus seperti kampanye, iklan, event, dan lainnya. Citra terbentuk karena permainan simbol dan asosiasi. Citra dalam suatu lembaga dibangun melalui persepsi atau kesan publik terhadap perusahaan tersebut. Pembangunan citra sesuai dengan identitas yang ingin ditampilkan oleh lembaga yang bersangkutan.

Citra Fanpage Santrionline dilihat dari desain foto profil, menunjukkan bahwa santri berkiprah di dunia virtual dengan visualisasi anak laki-laki yang memakai songkok dan bermain komputer dengan tulisan santri online. Songkok sebagai visualisasi pesan fashion nusantara yang umumnya dipakai kaum laki-laki. Anak laki-laki yang memakai songkok sebagai visualisasi sejarah pendirian Santrionline oleh santri (berjenis kelamin laki-laki) yang bernama Abdul Wahab. Desain logo dengan warna biru biasanya warna universal yang dipilih perusahaan untuk menyampaikan kehandalan, dapat dipercaya, dan komunikasi. Warna biru menggambarkan ketenangan dan memberikan kedamaian. Tulisan Santri Online menunjukkan nama media. Warna hijau pada tulisan santri menggambarkan suatu bagian dari Nahdhatul Ulama dan melambangkan kesuburan tanah Indonesia dan tulisan online berarti sedang berada di media sosial serta warna putih melambangkan kesucian (Anon n.d.)(lihat Gambar 2).

Berdasarkan klasifikasi citra dari Frank Jefkins dalam Soemirat dan Ardianto (2012) yang dikutip oleh (Yoni et al. 2017:5), jenis-jenis citra yang dikomunikasikan di Fanpage Santrionline.

Pertama, the mirror image (cerminan citra) yang merupakan bagaimana organisasi menduga citra organisasi tersebut dilihat oleh khalayak 


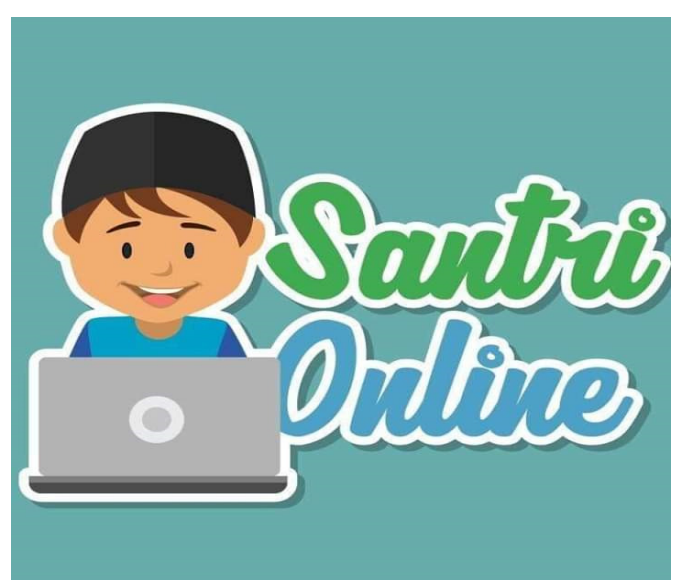

Gambar 2

Profil Fanpage Santrionline. Sumber: Fanpage Santrionline

eksternalnya. Berdasarkan visi dan misi Santrionline menduga sebagai media santri nusantara di mata khalayak.

Kedua, the current image (citra masih hangat) adalah citra yang sedang terdapat pada publik eksternal mengenai organisasi yang bersangkutan. Sebagian besar khalayak berdasarkan tingkat rekomendasi di Santrionline, menunjukkan bahwa Santrionline merupakan media santri dan termasuk dalam organisasi naungan Nahdhatul Ulama.

Ketiga, the wish image (citra yang diinginkan) merupakan citra yang diinginkan oleh organisasi. Citra ini diaplikasikan untuk sesuatu yang baru sebelum publik eksternal memperoleh informasi secara lengkap. Santrionline diharapkan menjadi media belajar santri, media berbisnis, media untuk melawan hoax dan menyebarkan perdamaian.

Keempat, the multiple image (citra yang berlapis) yaitu sejumlah citra dari individu, kantor cabang, atau perwakilan perusahaan yang lainnya yang dapat membentuk citra tertentu dari sebuah perusahaan atau organisasi. Citra yang terbentuk belum tentu sesuai dengan keseragaman citra seluruh perusahaan atau organisasi. Citra diri dari individu ditampilkan oleh CEO Santrionline sebagai pemuda berprestasi yang telah mendapatkan penghargaan pada tahun 2016 dari menpora (mentri pemuda dan olahraga) Indonesia sebagai pemuda inspiratif dan penghargaan dari KNPI (Komite Nasional Pemuda Indonesia) sebagai pelopor pemuda penggerak perdamaian serta sebagai pendakwah, pebisnis muda, dan motivator (Priyatin 2017).

\section{Pengaruh Komunikasi Islam Fanpage Santrionline}

Pengelolaan interaksi pada jaringan Facebook membutuhkan kebijaksanaan dalam penggunaannya untuk memainkan peran sosial dalam jaringan tanpa mengorbankan citra media yang dibentuk melalui komentar atau perilaku simbolik lainnya yang secara aktif dimaknai oleh pengguna lainnya. Pengelolaan petunjuk ekspresif dan penjelas pesan yang baik serta aspek pembahasan yang tepat pengguna, dapat mengarahkan interpretasi yang sama yang akan terbentuk pada penerima. Mereka juga akan menggunakan signifikan simbol yang diakui bersama baik berupa emotikon, teks atau gaya bahasa penjelas konteks pesan lainnya.

Interaksi tersebut sejalan dengan teori interaksi simbolik yang didasarkan pada makna yang terbangun sebagai hasil dari interaksi yang didasarkan pada pemaknaan bersama (shared common meaning). Pengelolaan identitas sosial 
berdasarkan nilai dan norma dimana makna tersebut dimaknai. Menurut Mead, pengguna juga memiliki standar nilai yang dimilikinya ketika menerima pesan dan menjadikannya acuan dalam mengolah makna simbol sebagaimana lingkungan dan maknanya. Proses interplay antara mind, self, dan society melalui aktivitas jejaring sosial dimana individu membangun pemaknaan (looking glass self) (Morissan 2017:128).

Membangun sebuah pemaknaan berdasarkan konsep diri adalah dengan melihat diri kita sebagaimana orang lain melihat kita melalui proses pengambilan peran (role taking) dan atau menggunakan perspektif orang lain dalam melihat diri kita. Konsep diri adalah keseluruhan persepsi kita mengenai cara orang lain melihat kita. Penilaian terhadap sikap diri (self attitude) dapat menggunakan dua kategori pernyataan yaitu pernyataan konsensual yang mengacu pada suatu kelompok tertentu atau identifikasi kelas dalam masyarakat (class identification), di antaranya, santri, orang Islam, warga $\mathrm{NU}$, warga Indonesia. Kategori kedua adalah pernyataan subkonsensual yaitu pernyataan yang bersifat tidak umum seperti orang shaleh, baik, senang, dan sebagainya. tentunya secara umum individu akan mengidentifikasi dirinya dalam kelas yang ada di masyarakat

Fanpage Santrionline yang memposisikan dirinya sebagai media santri Nusantara, dimana pada level pengalaman memang dikelola oleh para santri sehingga ide dan gagasannya pun dipengaruhi oleh jalan kehidupannya. Di sisi lain, para anggota komunitas pun megidentifikasi dirinya sebagai seorang santri karena sebagian telah merasakan kehidupan sebagai seorang santri seperti yang dialami oleh pengelola Santrionline. Ruang Fanpage pun yang memiliki budaya ala santri, NU, dan Indonesia dapat mempengaruhi seseorang ketika berada dalam lingkup ruang Fanpage Santrionline. Interaksi sosial di pandang dari interaksi simbolik terdiri dari tiga komponen, diantaranya tindakan sosial bersama, bersifat simbolik, dan melibatkan pengambilan peran.

Pada level pengalaman (experimental stories) menunjukkan bahwa topik yang diangkat dalam banyak konten merupakan representasi dari realitas yang terjadi di tengah masyarakat. Postingan yang terdapat dalam Fanpage Santrionline berisi suatu hal yang terjadi di dunia nyata dan viral di akun media sosial lain. Unggahan dari Fanpage Santrionline juga merupakan representasi dari kehidupan nyata kaum santri, seperti mengaji, hormat pada kyai, berbisnis, dan kegiatan dakwah seperti yang dilakukan oleh para pengelola Santrionline yang dituangkan dalam bentuk konten di media sosial.

Evaluasi strategi konten di Fanpage Santrionline oleh admin dapat dilihat dari alasan khalayak mengikuti Fanpage Santrionline. Komponen konten dari isi pesan, format penulisan, dan struktur pesan meningkatkan daya tarik khalayak berdarkan pengalamannya menggunakan media sosial.

"Ya menurut aku isi postingan mengenai orang $\mathrm{NU}$, terlebih masalah pesantren memang benar begitu adanya dan Fanpage ini merupakan langkah dari generasi muda NU untuk berperan dalam bidang apapun, termasuk di media online" (Al Farukh Goesle Salafi, wawancara via Messenger, 8 Juli 2019). 
"Saya sendiri sangat suka membaca di Fanpage Santrionline, karena pada cover atau judul pembukaannya menarik untuk dibaca, dan memberi manfaat pada akhir penutupannya" (Isnal, wawancara via Messenger, 5 Juli 2019).

Pada level pengalaman, perhatian dari pengunjung tentunya hal yang penting untuk mengetahui sejauh mana postingan tersebut berpengaruh bagi penikmatnya. Fanpage Santrionline eksis di media sosial sebagai salah satu media santri. Berdasarkan pengalaman dari pengunjung Santrionline, menyatakan bahwa Fanpage Santrionline memiliki manfaat dan sudah terpercaya sebagai media yang digunakan masyarakat untuk berkomunikasi karena selalu merujuk pada pendapat ulama dan tidak menyebarkan hoax. Kita dapat melihat bahwa budaya ala santri adalah merujuk pada kyai, sehinga masyarakat siber tetap mempertahankan budaya tersebut dalam hal belajar keilmuan. Hal ini sejalan dengan asumsi teori ekologi media Mcluhan bahwa media infuse every act and action in society dan media fix our perceptions and organize our experiences (Morissan 2017:38). Fanpage Santrionline dapat memengaruhi persepsi dan tindakan dalam masyarakat, termasuk tindakan memilih suatu informasi dari Fanpage Santrionline, mengomentari, dan menyebarkannya.

"Saya mengikuti Fanpage Santrionline karena postingannya sangat bermanfaat dimana selalu mengambil rujukan 'ulama, tentunya ulama NU. Kan banyak tuh sekarang ustadz-ustadz baru, karena saya awam saya lebih baik memilih akun yang jelas gitu, bukan berarti saya tidak mau belajar aliran lain. Terus di Santrionline ini saya bisa tau mana yang hoax mana yang ngga" (N Nurjannah, wawancara via Messenger, 5 Juli 2019).
Pada level pengalaman Santrionline dikenal dari hasil karya-karya santri yang diunggah. Penjualan produk dari Santrionline dapat diketahui masyarakat melalui sistem online melalui strategi komunikasi untuk meningkatkan brand awareness dan brand attitude masyarakat melalui iklan produk yang diunggah, kemudian akan memengaruhi keputusan membeli agar dapat memakai fashion ala santri.

"Alhamdulillah, Fanpage Santrionline sangat bermanfaat dan memberi manfaat. Disana menjual hasil karya-karya santri, saya belum pernah membeli produknya, tapi kapan-kapan saya membelinya" (Isnal, wawancara via Messenger, 5 Juli 2019).

Eksistensi dari Fanpage Santrionline tentunya didukung oleh para pengikutnya. Citra media dibentuk dari strategi media dan didukung dengan strategi konten untuk membentuk image positif dan menciptakan kepercayaan masyarakat. Kepercayaan masyarakat dimulai dari rutinitas Santrionline dalam menyebar informasi, selanjutnya timbul rasa penasaran untuk melihat dan menilai. Rutinitas pengunggahan informasi akan membuat masyarakat menjadi semakin mengenal Fanpage Santrionline. Selanjutnya akan melakukan tindakan bersama (join action) dari sekelompok orang untuk mengakses Fanpage Santrionline, diantaranya memberikan like sebagai peninggalan jejak dan juga simpati, memberikan komentar dan berdiskusi, bergabung grup, membagikan konten Fanpage Santrionline dan menulis postingan di kolom postingan.

Tindakan ini selaras dengan konsep Mead yang menyebut bahwa tindakan sosial melibatkan hubungan tiga komponen yaitu gerak atau 
isyarat (stimulus) dari orang lain, tanggapan terhadap isyarat (respond), dan adanya hasil (action) (Morissan 2017:127). Konsep ini juga sesuai dengan tindakan komunikasi individu yang membagikan status atau konten di kolom "tulis status" di Fanpage, namun tidak mendapat tanggapan dari pengunjung lain. Individu melakukan aktivitas interaksi dengan mengirimkan di kolom postingan komunitas, diperoleh dari pengalaman individu menggunakan media sosial, terutama Facebook dalam mengunggah konten dan juga melihat pengguna lain mengirim status di Fanpage.

Pengunjung saling memberikan pengaruh kepada pengunjung lain mengenai konsep diri sebagai santri sehingga Fanpage merupakan ruang pesantren yang digunakan untuk belajar dari kyai dan ulama. Santri didefinisikan sebagai orang yang memiliki pemahaman agama yang baik dan tinggal di pesantren sehingga menjalankan nilai, norma, etika, dan budaya pesantren. Konsep diri (self) khalayak merupakan hasil dari berfikir (mind) yang terkait dengan keberadaan komunitas di Fanpage Santrionline (society). Dalam interaksi sosial, pikiran (mind) dan konsep diri (self) aktor yang merupakan bagian dari esensi tindakan sosial, sehingga pengunjung saling memengaruhi, menyesuaikan diri, dan mencocokkan tindakan-tindakan mereka.

Transformasi citra Santrionline tidak hanya sebatas di dunia virtual melainkan juga aktivitas di dunia nyata. Komunikasi dibentuk melalui saluran event diantaranya halal bihalal, bazar, pengajian, kegiatan seminar oleh CEO Santrionline di beberapa kampus, dan kegiatan belajar dan mengajar bersama Santri Progresif.

\section{Kesimpulan}

Strategi komunikasi Islam dalam Fanpage Santrionline terdiri dari strategi konten dan strategi media. Strategi konten terdiri dari isi, format, dan strukrur pesan (pengendalian pesan). Sedangkan Strategi media berisi peningkatan citra diri media melalui saluran media dan saluran event. Pengaruh komunikasi agama dirasakan oleh pengikut Fanpage Santrionline dalam belajar ilmu agama di Fanpage Santrionline sehingga berpengaruh pada tindakannya. Fanpage yang dikelola oleh para santri, sebagai media santri Nusantara tentunya telah memiliki pengalaman dunia santri yang dituangkan dalam ruang virtual berbentuk konten gambar, tulisan, dan video.

Pada level ruang media (media space) Fanpage Santrionline merupakan karya santri dengan visi sebagai media santri nusantara, dengan semboyan dari santri, oleh santri, untuk negeri. Fanpage santrionline digunakan sebagai media komunikasi agama ala santri, belajar agama, dan berbisnis. Fanpage dapat diakses oleh khalayak dengan menyukai dan mengikuti Fanpage.

Pada level dokumen media (media archieve) konten di Fanpage Santrionline merupakan konten narasi alternatif yang menyampaikan pesan perdamaian. Waktu pengelolaan konten belum terjadwal. Pada level objek media (media object), Pola komunikasi segala saluran sehingga terjadi komunikasi dengan komunikator (admin) dan pengunjung (komunitas). Tanggapan khalayak berupa komentar positif dan komentar negatif pada setiap kolom komentar. Interaksi yang dominan antar ang- 
gota komunitas walaupun mereka sebenarnya tidak saling mengenal, namun interaksi juga terjadi dengan admin Santrionline. Mereka akan saling memberikan tanggapan di kolom komentar mengenai postingan admin Fanpage Santrionline. Di sisi lain, anggota komunitas juga dapat menjadi produsen untuk mengunggah konten di Fanpage santrionline, namun konten tersebut hanya muncul di kolom komunitas dan tidak muncul di beranda Fanpage. Interaksi di kolom komunitas oleh para anggota komunitas Fanpage tidak sebanyak seperti pada kolom komentar konten yang diunggah admin. [

\section{Daftar Pustaka}

Ali-Fauzi, Ihsan. 2019. "Melawan Hasutan Kebencian."

Anderson, Jon W. 2003. "New Media, New Publics: Reconfiguring the Public Sphere of Islam." Social Research 70(3):887-906.

Anon. n.d. "Arti Warna dan Simbolisme Bagaimana Menggunakan Kekuatan Warna pada Merek Anda." Canva.com. Diambil (https://www.canva.com/id_id/ belajar/arti-warna-dan-simbol-darimerk/).

Arifianto, Alexander R. 2018. "Islamic Campus Preaching Organizations in Indonesia: Promoters of Moderation or Radicalism? Asian Security." Asian Security 1-20.

Asosiasi Penyelenggara Jasa Internet Indonesia. 2018. "Hasil Survei Penetrasi dan Perilaku Pengguna Internet Indonesia 2018." apjii.or.id. Diambil (https://apjii.or.id/ content/read/39/410/Hasil-SurveiPenetrasi-dan-Perilaku-PenggunaInternet-Indonesia-2018).
Astaphala, I. Wayan Gede. 2019. "Presiden: NU Memiliki Komitmen Kebangsaan." KompasTV, Januari 31.

Ayun, Primada Qurrota, Mutia Rahmi Pratiwi, Kheyene Molekandella Boer, Kristina Andryani, Didik Haryadi Santoso, Khairul Arief Rahman, Arif Kusumawardhani, Filosa Gita Sukmono, Puri Kusuma Dwi Putri, dan Fajar Junaedi. 2014. Cyberspace and Culture: Melihat Dimanika Budaya Konsumerisme, Gaya Hidup, dan Identitas dalam Dunia Cyber. Yogyakarta: Buku Litera.

Effendy, Onong Uchjana. 2008. Dinamika Komunikasi. Bandung: Remaja Rosdakarya.

Effendy, Onong Uchjana. 2017. Ilmu Komunikasi Teori Dan Praktek. 28 ed. Bandung: Remaja Rosdakarya.

Eka, Randi. 2018. “Laporan DailySocial: Distribusi Hoax di Media Sosial 2018." dailysocial.id, Agustus 16.

Franzia, Elda, Yasraf Amir Piliang, dan Acep Iwan Saidi. 2016. "Visualisasi Identitas Islam dalam Komunitas Virtual Palanta Urang Awak Minangkabau." Mudra Jurnal Seni Budaya 31(2):167-77.

Gumilar, Gumgum. 2017. "Literasi Media: Cerdas Menggunakan Media Sosial dalam Menangani Berita Palsu (Hoax) oleh siswa SMA." Jurnal Pengabdian kepada Masyarakat 1(1):35-40.

Hasanah, Hasyim. 2016. "Arah Pengembangan Dakwah melalui Sistem Komunikasi Islam." At-Tabsyir: Jurnal Komunikasi Penyiaran Islam 4(1):131-56.

Hefni, Harjani. 2015. Komunikasi Islam. Jakarta: Prenada Media Grup. 
Hojsgaard, Morten dan Margit Warburg, ed. 2005. Religion and Cyberspace. Abingdon, UK: Routledege.

KompasTV. 2017. "Santri Online, Media Online Belajar Para Santri."

Lim, Merlyna. 2002. "Cyber-civic Space in Indonesia: From Panopticon to Pande monium?" International Development Planning Review 24(4):383-400.

Morissan. 2017. Teori Komunikasi Massa. Bogor: Ghalia Indonesia.

Nasrullah, Rulli. 2017. Etnografi Virtual: Riset Komunikasi, Budaya, dan Sosioteknologi di Internet. Bandung: Simbiosa Rekatama Media.

Netmediatama. 2018. "Saliha - Santri Online, Penyejuk Ditengah Banyaknya Hoax Bertebaran di Media Sosial."

Nuruddin. 2018. Media Sosial Agama Baru Masyarakat Milenial. Malang: Intrans Publishing.

Pertiwi, Wahyunanda Kusuma. 2019. "Facebook Jadi Medsos Paling Digemari di Indonesia." tekno.kompas.com, Februari 5.

Prasetya, Hendri. 2017. "Virtual Etnography (Kajian Etnografi Komunikasi pada Media Sosial Facebook di Indonesia)." Wacana: Jurnal Ilmiah Ilmu Komunikasi 12(4):35571.
Pratomo, Yudha. 2019. "APJII: Jumlah Pengguna Internet di Indonesia Tembus 171 Juta Jiwa." tekno.kompas.com, Mei 16.

Priyatin, Slamet. 2017. "Cerita Wahab, Pria Tak Lulus SMP yang Menjadi Pemuda Inspirasi." Kompas.com, Maret 6.

Ridho, Subkhi. 2017. "Kelas Menengah Muslim Baru dan Kontestasi Wacana Pluralisme di Media Sosial." Jurnal Pemikiran Sosiologi 4(2):88-103.

Said, Nur dan Izzul Mutho, ed. 2017. Santri Membaca Zaman: Percikan Pemikiran Kaum Pesantren. Yogyakarta: Aswaja Pressindo.

Timpal, Nicky. 2016. "Pengaruh Brand Aware ness dan Brand Attitude terhadap Keputusan Pembelian Handphone Merek Nokia (Studi Kasus pada siswa SMA dan SMK di Kota Manado)." Jurnal Berkala Ilmiah Efisiensi 16(1):308-17.

Ulya, Ulya. 2018. "Post-Truth, Hoax, dan Religiusitas di Media Sosial." Fikrah: Jurnal Ilmu Aqidah dan Studi Keagamaan 6(2):283-302.

Yoni, Ni Luh Kade Diah Pradnya, Ni Nyoman Dewi Pascarani, dan I. Dewa Ayu Sugiarica Joni. 2017. "Strategi Komunikasi Melalui Media Sosial dalam Pembentukan Citra Balebengong sebagai Media Jurnalisme Warga." E-Jurnal Medium 1(1). 